\title{
Cultural Heritage and Its Legal Protection in Indonesia Since the Dutch East Indies Government Period
}

\author{
Isnen Fitri' ${ }^{1}$ Yahaya Ahmad ${ }^{2}$, Ratna ${ }^{3}$ \\ Department of Architecture ${ }^{1}$ \\ University of Sumatera Utara, Medan, Indonesia ${ }^{2}$ \\ Centre for Urban Design, Conservation and Tropical Architecture (UCTA) ${ }^{2}$ \\ University Malaya, Kuala Lumpur, Malaysia ${ }^{3}$ \\ isnen@usu.ac.id, yahaya@um.edu.my,ratnasusatyo@yahoo.co.id
}

\begin{abstract}
The legal protection of cultural heritage in Indonesia had begun since the issuing of Monumenten Ordonnantie No.19 year 1931. The Athens Charter, which has marked a milestone in global collaboration for heritage conservation protections, was published four months later after the issuance of MO. This paper discusses the historical outline of the legal aspects of the cultural heritage protection in Indonesia from the Dutch East Indies Government era until now. Also, it purposes to review the contents and scope of the heritage laws in every political period of Indonesia, as well as its relevancy with the international instruments issued within the same period. The study relied on a literature review and historical data from various sources on cultural heritage legislation in Indonesia. It highlights the aspect legislation of cultural heritage in Indonesia still have many loopholes and unparalleled to the global trend.
\end{abstract}

Keywords: cultural heritage, legal protection, Indonesia

\section{INTRODUCTION}

The aspects of heritage protection legislation in Indonesia were marked by the issuance of Monumenten Ordonnantie Staatsblad 238 No.19 year 1931 (the MO Stbl 238 year 1931) that only four months before the publication of the Charter of Athens as a milestone in the history of global collaboration in heritage conservation efforts. From the reign of the Dutch East Indies up to the current government, there are three laws pertaining to the protection and preservation of cultural heritage in Indonesia, MO Stbl 238 1931, Law No.5 year 1992 and Law No. 11 year 2010 onCultural Property Conservation.

This paper aims to provide an overview of legislation aspects of cultural heritage protection as well as its management in the conservation efforts in Indonesia since the reign of the Dutch East Indies to the present government. Specifically, the study aims to analyze and describe the three laws that have and are being forced to protect the cultural heritage that is Monumenten Ordonnantie Staatsblad 238 No.19 year 1931, the Law No. 5 of 1992 and Law No. 11 of 2010 on Cultural Property Conservation. Discussion of results in this study includes an analysis of the two laws enacted before the current Law No.11/2010 on Cultural Property Conservation. Analysis of the three laws was prioritized to the terminology of cultural heritage, category of protected cultural heritage which is associated to the relevance of legislation development and guidelines at the international level. Thus, the progress of the protection of cultural heritage in Indonesia could be known.

This study categorizedas library research where the data collection method in this research conducted through a library search as the data sources. This study is qualitative and descriptive analytic and also comparative, starting with a literature review and compilation of cultural heritage protection legislation aspects in Indonesia, especially the laws that are relating to the curent Law to protect of cultural heritage in Indonesia as 
well asat the international level. The critical analysis focused on legislation on the protection of cultural heritage at every period as described previously, particularly the current legislation, to know the weaknesses and strengths of any legislation. Recommendation of the results from a critical review presented at the conclusion of efforts to improve the protection of cultural heritage legislation Indonesia in the future.

Until now, although over one hundred conventions, charters, and the doctrines of heritage conservation at the international level have been published, the only one that has been ratified by the Indonesian Government, namely UNESCO Convention for the Safeguarding of the Intangible Cultural Heritage (2003) into the Presidential Decree 78 of 2007. It is a positive since Indonesia has no law of Intangible Heritage so that it can be a reference to arrange the new law or regulation of intangible heritage. This paper discusses the aspect of the laws for the protection cultural heritage since the Dutch Era until the present. It also analyzes the influence of international conventions, charters and doctrines towards the development of the legal aspects of the protection of cultural heritage of Indonesia through literature review and collecting historical documents on conservation effort in Indonesia from various sources. The result of the paper is expected to contribute for arranging and accomplishing the implementing regulations that contain further stipulations in regards to the Law No.11 of 2010.

\section{DISCUSSION}

The Archaeological Service was in charge to conduct the investigation, exploration and inventory, planning and rescuing the cultural heritage from extinction, which was covered by the passion of academic view and focused on artifacts. The scope of work of this institution is still around the Java Islands and Madura. In the historical synopsis of cultural heritage legislation in Indonesia has been noted that interest in documentation and inventory of cultural heritage has grown since the beginning of the 18th century. The interest in it is growing since the publication of the book entitled 'D'Amboinsche Rariteitkamer' in 1705 by GE Rumphius, a botanist and zoologist, who also work as a VOC staff[1]. The development of the protection for heritage in Indonesia from the aspect of legislation strongly associated with political events. Therefore, the discussion regarding the protection of heritage in Indonesia will be divided into four periodization that is first, during the era of the Netherlands East Indies (NEI) sovereignity, second, the period of the Independence and the old Order, and then third period, the New Order and the fourth, during the Reform Era to the present. To review the protection of cultural heritage in Indonesia, so any developments in the period would be compared to the conventions, events, and trend occurring of the international level.

\section{A. The era of the Dutch East Indies sovereignty}

The first Indonesia heritage law was published in 1931 named Monumenten Ordonnantie. This monument act has 14 chapters covering definition and terminology, registration process and procedure and monitoring of monuments, including sanctions for violations, as well as the office in charge of the protection for cultural heritage. At a global level, a term of the monument was used since the mid-17th century until the mid-20th century. As disclosed by Prott and O'Keefe (Prott, 1992), before using the term of cultural heritage, a law respectively using the terminology 'monument,' 'sites,' 'antiquities' and 'relics.' Using the word 'monument' in the MO Stbl $238 / 1931$ was paralleling to the previous term on a global level in 1904 at Sixth International Congress of Architects in Madrid as well as in the Charter of Athens 1931. However, the description of monument within the MO 238/1931 was clearer than these two international instruments. In the Recommendation of Madrid Conferenceissued in 1904described two types of monuments: living and dead monument, and The Athens Charter only mentioned the monument as the object which has artistic, historic, and scientific interest. The term of a 'historic monument' that was firstly described in the Venice Charter (1964) was still unclear and a year later clarified in section 3 in the Reporter of the Constitutive Assembly ICOMOS year 1965 (Yahaya, 2006). J. Jokilehto (1986) in his thesis explained in Greek, word for 'monument' was related to memory while, in Rome, the concept contained even political and ethical issues. Often there was a greater respect for the original builder 
than for the material form of the building. Further, he described the Latin text speaks "momumenta," here translated as a memorial. It derives from the verb "moneo", which means to remind, to recall, to admonish, to warn, to suggest, to advise. And "Monumentum" so means, memory, memorial, funeral monument, document, something that recalls memories, and it was used concerning buildings, statues, or writing.

The terminology of monument in the MO Stbl 238 of 1931 was stated in the Article 1 included three categories of monuments: first, movables and immovable objects of man-made having great importance for the prehistory, history or art; second, objects viewed from the perspective palaeoanthropology, and third, sites. Accordingly, it is concluded that the monument defined in the law tend to archaeological objects such as artifacts, buildings, and sites that categorized as tangible heritage and a single object. The monuments of nature such as flora and fauna, however, were not regulated by this law. The other articles concerned on the registration, determination of compensation as well as the access to control and violation of the provision. It overall illustrated that the protection of cultural heritage was mere as government's responsibility and devote for the country. Community involvement was intended to devotion to the state while the rights of society itself less accommodated. Yet, this tendency at the the moment was also happening at the global level. Maintaining the Integrity of the Specifications

\section{B. The Period of after independence and Old Order (1945-1965)}

The basic foundation of cultural heritage protectionafter the Proclamation of Indonesian Independence in 1945 was explicitly mentioned in Article 32 of The Constitution of the Republic of Indonesia "the state shall advance the national culture of Indonesia" (Soebadio, 1985). After the independence, the MO Stbl 238 year 1931 was still valid without any fundamental changes in its substance. There was only a slight adjustment in heritage management to adapt the newly government structure. The leading institute that took responsibility for the protection was the Cultural Department within the Ministry of Education and Culture which previously was led by
Ministry of Education and Religious Affairs. Because uncertain political climate after Indonesia independence from 1945-1949, conservation activities in Indonesia was relatively dormant for the time being. In 1947, there was a dualism in leading of the protection for cultural heritage whereby the NEI Government finally reoccupied Indonesia and revived the Oudheidkundige Dienst (Soekmono, 1992).

The protection of cultural heritage in the urban context received attention after issuance the Town Planning Ordinance (Stadsvormings ordonantie or SVO) in 1948. In fact, the draft of the law published in 1938, however, because the circumstances during WW II and uncertain political climate after the Indonesia Independence, it was never enacted and implemented until 1948.

Since the limitation of the MO Stbl 238/1931 to control and prevent the cultural heritage from the violation and theft, the government issued several instructions, decrees, and other regulations during the Old Order. Accordingly, the situation at the time being illustrates that the MO 238/1931 with has no significant changes in its contents from the Dutch era need to revise in order to address the currently issues. While, at the international level, this was a remarkable period encouraged by the establishment of the international organizations such as The International Union for the Conservation of Nature (IUCN) in 1948, UNESCO (1950), International Institute for Conservation of Historic and Artistic Works (IIC) in 1950, International Council of Museums (ICOM) in 1952, The International Centre for the Preservation and Restoration of Cultural Property (ICCROM) in 1956, The International Council on Sites and Monuments (ICOMOS) in 1965. During this period, these organizations had published several doctrines and conventions. Among them which were most influential were the Hague Convention for the Protection of Cultural Property in the Event of Armed Conflict with Regulations for the Execution of the Convention (1954) and the Venice Charter (1964). After publishing the Hague Convention by UNESCO, the international heritage community has used the term 'cultural property' instead of 'monument'. Since then, this term was often used by the countries within their heritage legislation. This convention identified the notion of cultural property as monuments of architecture, art or 
history, archaeological sites, groups of buildings, works of art and collections. Compared to during the Ducth Indies Government Period, those progressesof the international levelduring this periodseem that have no immediate influences to the improvement of protection and management in heritage conservation of Indonesia. It can be seen by the content of the heritage legislation issued in the Old Order era.

\section{The New Order Government Period (1966-1997)}

The MO Stbl 238 of 1931 was still valid and implemented during the reign of the New Order Government. At the end Rencana Pembangunan Lima Tahun (Repelita or Five-Year Development Plan)I(1969-1973), MPR (The people's consultative assembly) issued a resolution called TAP MPR No.IV/MPR/1973 concerning on the outlines of state policy in which there was the explanation of national cultural policy as the basis for the cultural development planning.Then, without changing the meaning and purpose, the resolution was updated in 1988 as TAP MPR No.II/MPR/1988. Besides, during the New Order led by President Soeharto also issued more than a dozen of decisions and instructions in regards to heritage protection and management at the ministerial and presidential regulations. The regulations were purposed to support and solve the problems in the protection and management of cultural heritage in Indonesia at the time being. Those regulations have reflected that the MO Stbl 238 of 1931 were no more unable to give solutions for the problems and situations facing during this period. In fact, the additional regulations were worked ineffectively after the years due to conflicting provisions of these decrees and weakness in the implementation. Also, several significant obstacles were the lack of coordination among government agencies that in charge of protection and conservation efforts. Therefore, cases of theft, vandalism and destruction of cultural heritage still continued.

By the early 1990's, the MO Stbl 238/1931 was still valid. Finally,after The Indonesian Government accepted the UNESCO Convention 1972 in 1980's, Indonesian government issued a new law on the cultural property to amend the MO Stbl 238/1931 called the Law No. 5 on Benda Cagar Budaya (BCB) translated into 'Items of Cultural Property'in 1992. As mentionedpreviously, the terminology of 'cultural property' was initially used in the Hague Convention (1954). Later, after issuing the Unesco World Convention in 1972, the international heritage communities preferred to use the term 'cultural heritage' instead of 'cultural property.' Some analytical answer may be given to why the phrase 'cultural heritage' has been more appropriate in the context of the recent development of the cultural heritage studies. Prott and O'Keefe clearly argued, in their 1992 article, the reasons to use the terminology of cultural heritage rather than cultural property. Furthermore, he asserted that the phrase 'cultural heritage' is rightfully superseding 'cultural property.' The existing legal concept of 'property' does not, and should not try to, cover all that evidence of human life that we are trying to preserve. Property connotes ownership and this, as stated above, has been defined in the Common Law as meaning the right to exploit, to alienate, and to exclude. Therefore, the fundamental policy behind property law has been seen as the protection of the rights of the possessor. While, the basic policy behind cultural heritage law is a protection of the heritage for the enjoyment of present and later generations. This means not only physical protection but the possibility of access for persons other than the owner(Prott \& O'Keef, 1992). The strongest argument against the use of the term "cultural property" is that it is too limited to encompass the range of possible elements-both tangible and intangible-which can comprise the cultural elements being described (Blake, J, 2000).

The definition of cultural property items in the BCB law has indeed included a single object or group and then followed by the phrase 'must have at least 50 years of age'. Despite there was an explanation that the area around the site should be protected; however, the description concerns more about the safety of the artifacts or sites, not relies upon the awareness of the relationship between the artifacts or the site environment. Therefore, the notion of the group means more to the group of building instead of in the framework of the spatial or area (Tanudirjo, 2007). It seems that during this period, the conservation still oriented to the object that was antiques or archeological objects. While, a group of buildings and conservation area have been very much discussed in world-wide during this period. A lot of charters, resolutions, and recommendations mentioned about protecting 
areas, regions and small historic town were published by UNESCO and ICOMOS ranging from 1960 to 1992 . Other issues wereoften discussed at the global during this period such as urban heritage conservation, integrated conservation with a multidiscipline approach, decentralization of the heritage management, heritage value or significance assessment and community participation. Meurs (2007) asserted the sixties and seventies were the time of urban renewal in the European inner cities. In Indonesia, urban conservation issue has blown up from the early 1971, wherein, at the time the planners had much discussed on conservation development program for Jakarta city (Damais, 1978). Since then, several provincial and municipal government initiate to create their heritage listing. However, the BCB Law did not described decentralization concept in heritage management yet. Thus, it still showed the concept of centrality in term of registration, planning, and management of cultural heritage as applied in the previous period. UNESCO, ICOMOS, and other international heritage organizations have published a dozens conventions, charters and recommendations of cultural heritage conservations regarding the above issues after the WW II until the 1990's. The integrated conservation and multidisciplinary approach to heritage management were initiated in the Amsterdam Declaration (1975) and the Recommendation concerning the Safeguarding and Contemporary Role of Historic Areas (UNESCO, 1976). Furthermore, most of the conventions, charters, declarations, resolutions and recommendations on the protection and preservation of heritage was published after the mid-1970s stated that community involvement in the protection and conservation of cultural heritage should be encouraged and enhanced. Since the late 1960's, the British planning system allow public involvement in the planning process (Larkham, 1996, p. 65).Whereas in the Article 18 of the law and Article 42 of the Government Regulation No.10 year 1993 have stated the concept of community involvement in heritage conservation. Nevertheless, the concept and the fact still showed on the level of sharing information or consultation not at collaboration level. During this period, the heritage conservation are mainly still being the government responsibility since all items of cultural property are controlled by the State
(Article 4 and 18,the BCB Law). Besides, the Indonesian Government during this period still ignored the issue of a multidisciplinary approach, it can be seen cearly whereby the protection of heritage in government administration structure were still dominated by the archaeologist.

\section{The Reform Era (1993-Present)}

In October 2010, Indonesian Government published the law No.11 on Cagar Budaya (CB) or Cultural Property Conservation(Pemerintah Republik Indonesia, 2010). The Act was expected to be a fundamental base as well as the new perspective to protect and organize the cultural heritage in Indonesia being better comprehension. The newly aspects stated in the CB Law No11/2010 are heritage category, decentralization of the heritage register comprises three levels: national, provincial and municipal, and a multidisciplinary approach in heritage conservation work. Despite the CB Law No.11/2010 has implied various aspects which were not mentioned in the previous law, nonetheless, the expectation towards the $\mathrm{CB}$ law No.11/2010 is not equal to the reality. There is a huge and anxious gap between them (Tanudirjo, 2010).

There are several arguments against the CB Law No.11/2010 as follows; firstly, the use of the term 'Cagar Budaya' still refer to the phrase 'cultural property' focusing on material culture heritage (comprise movable or immovable) as the global trend in 1960's such as cultural artifacts and architectural monuments. The law has also included classification of the historical area or district but has not yet protected the intangible cultural heritage. Meanwhile, most of other countries have amended their heritage act to protect both tangible and intangible heritage. As long established notions in the global trend, the focus of conservation has changed from the material to the so-called immaterial or intangible aspects of heritage. Many heritage experts and scholars asserted the notion and scope of 'cultural heritage' are diverse and experiencing expansion from 1980's in paralleling with the development of information technology and social contemporary community. A lot of Asian countries have revised their law to protect the category of ICH such as Malaysia, Vietnam, South Korea, China, and Japan, etc. In fact, before issuing the CB Law in 2010, the 
Indonesian Government issued the Presidential Decree No.78 in 2007 anticipating the global trend for the intangible heritage conservation. The efforts to safeguard the ICH followed by the issuance of Joint regulation of the Ministry of Home Affair and Ministry of Culture and Tourism regarding Guidelines for Execution of Duties and Responsibilities of Local Government in Preservation of Culture. The Indonesian government today are establishing another legislation 'Indonesian Cultural Act.' The People's Representative Council of Indonesia now has been accomplishing the legal draft on the Indonesia Cultural Act. The law protects on both cultural heritage and intangible heritage. While, on the other hand, the government regulation of the implementation guideline for the CB Law has not published yet. Thus, the current situation in Indonesia seems rather chaotic regarding the protection for cultural heritage.

The next another point that needs to be criticised of the CB Law No.11/2010 is the definition of each heritage categories are still not proper and narrow. As argued by D.A. Tanudirjo (2010) that a few key points in the CB Law shows partially, inappropriate in the term of academic view, and as well as quite disturbing that can lead to misunderstandings. For instance, the conservation area or district shall mean "the geographical space unit having two sites or more located adjacent to and showing the typical spatial characteristic." If referring to this definition, the Sangiran Early man Site cannot be designated as a conservation area. Similarly, the concept of criteria for cultural heritage designation as mentioned in the Article 5 to be defined as narrowly and clearly illustrates that the act is still focused on antiquities and archaeological objects because of must have the age of 50 (fifty) years or more. Therefore, it makes sense if Tanudirjo mentions CB Law as Law on the Antiquities things or archaeological object of Indonesia. Besides, it is noteworthy of the CB Law that has included the category of underwater cultural heritage, even though there is no explicit definition and description of it. It seems that the conservation of the underwater cultural heritage treatment equated with the protection of cultural heritage in the land (Tanudirjo, 2010). Perhaps, the elucidation will be mentioned in the government regulation of the Act which still has not published yet. Moreover, the Indonesian government by the present has not accepted and adopted the UNESCO Convention (2001) on the Protection of the Underwater Cultural Heritage as a reference for revising the national legislation. This heritage classification is important to protect because Indonesia as a maritime country that has rich of the underwater cultural heritage.

Then, the third, the legislation has no elucidation of the definition and concept of cultural significance or a cultural value corresponding to designation as heritage. On the other hand,it becomes a crucial issue at the global level from 1980 's to the present. Moreover, the term of 'cultural significance " is not something new. It has stated in the Venice Charter (1964), but the term has expanded rapidly since the Burra Charter (1979) was published. The conservation of sites of cultural significance has been the main objective of management programs and projects in heritage areas for approximately the last 30 years (Pereira, 2007). In the 1990s, UNESCO started to require a Statement of Cultural Significance to be attached to applications for inclusion of sites on the World Heritage List. This fact has confirmed the importance of the concept of 'cultural significance' (Zancheti, Hidaka, Ribeiro, \& Aguiar, 2009, p. 47) As stated Burra Charter, the aim of conservation is to retain the cultural significance of historical asset. Influenced by this charter, today many countries recognize the importance of identifying values, thus followed by establishing the standards or criteria for the heritage significance assessment corresponding to designation as a heritage. Today, the heritage planning and management based its significance have become a contemporary trend in heritage conservation.

The last critique for the CB Law No.11/2010 still apparently shows the domination role of government in the context of old paradigm as stated in the Article 13 "the cultural conservation area can only be owned and/or controlled by the State, except those owned on the hereditary basis by the indigenous people." Referring definition of the Conservation Area in the Article 1 and the statement of the above article, this can be imagined how many budgets that should be provided by the government to own and conserve a conservation area. Meanwhile, in reality, we often face the inconsistency of the government whether at the national, provincial and local level for cultural 
heritage conservation such as the case of the demolition of historic buildings in the several towns after obtaining permission from the government. Besides, there are numerous weaknesses in its implementation particularly on the commitment of the government to give compensation for the owners who safeguard the cultural heritage. In the CB Law, the role of heritage expert is further enhanced and legitimated by the provision of a certificate. Today, the government focuses on training and certificating the heritage experts of multidisciplinary backgrounds for distributing in national, provincial and municipal level. This matter is contradictive with the global trend whereby increasingly recognized that the responsibility of conservation neither the domain experts alone nor the government, but also linked to the local communities as the owners of heritage itself. Public needs to be responsible and participate in decision-making (Cheung, 2011; Chirikure \& Gilbert Pwiti, 2008; Christina Aas, Ladkin, \& Fletcher, 2005; Macdonald, 2011).In summary, it can be concluded that there is no progress conceptually on the community involvement for heritage conservation in the $C B$ Law No.11/2010. Even though the dominance of the archeological profession with old paradigm approach is in reality still strong, unless the CB Law has state the aspect of mutlidisciplinary approach. It has become a trend everywhere that cultural heritage conservation works are not relying on a single individual or a profession anymore. The responsibilities start linking with the conservation of other specialties, so it becomes interdisciplinary and multidisciplinary.

\section{CONCLUSION}

It concludes that there are three laws enacted the heritage protection in Indonesia, firstly the Monumenten Ordonnantie (1931-1992), secondly, the Law No.5/1992 on Cultural Property Conservation (1992-2010), and thirdly, the Law No.11/2010 on the Conservation of Cultural Property as shown in the table 1 below.
Table 1. Heritage Legislation and management in Indonesia since Dutch Era

\begin{tabular}{|c|c|c|c|}
\hline & $\begin{array}{c}1931- \\
1992 \\
\end{array}$ & 1992-2010 & $\begin{array}{c}2010 \text { - } \\
\text { Present }\end{array}$ \\
\hline $\begin{array}{c}\text { Heritage } \\
\text { Law }\end{array}$ & $\begin{array}{l}\text { Monumen- } \\
\text { ten } \\
\text { Ordonantie } \\
\text { ( } 238 \text { Stbl } \\
\text { MO in } \\
1931 \text { ) }\end{array}$ & $\begin{array}{l}\text { Law No. } 5 \text { of } \\
1992 \text { on the } \\
\text { Conservatio } \\
\text { n of Cultural } \\
\text { Property }\end{array}$ & $\begin{array}{l}\text { Law No. } 11 \text { of } \\
2010 \text { on the } \\
\text { Conservation } \\
\text { of Cultural } \\
\text { Property }\end{array}$ \\
\hline $\begin{array}{c}\text { Heritage } \\
\text { Scope } \\
\text { Protection }\end{array}$ & $\begin{array}{l}\text { Tangible } \\
\text { Heritage } \\
\text { includes } \\
\text { Movable } \\
\text { Heritage, } \\
\text { Immovable } \\
\text { Heritage, } \\
\text { Sites }\end{array}$ & $\begin{array}{l}\text { Tangible } \\
\text { Heritage } \\
\text { includes } \\
\text { Movable } \\
\text { Heritage, } \\
\text { Immovable } \\
\text { Heritage, } \\
\text { Sites }\end{array}$ & $\begin{array}{l}\text { Tangible } \\
\text { Heritage } \\
\text { includes } \\
\text { Movable } \\
\text { Heritage, } \\
\text { Immovable } \\
\text { Heritage, } \\
\text { Groups of } \\
\text { building, } \\
\text { District,Sites }\end{array}$ \\
\hline
\end{tabular}

By reviewing the historical synopsis of cultural heritage protection and management in Indonesia from the Dutch era, it is noteworthy that the MO Stbl 238 published in 1931 is appropriate and in parallel to the developing theory and trend of the global level at the time being. However, during the Old and New Political Order, the heritage legislation, and policy has begun to unparalleled with trends and theories developing in the international level that potentially cause problems and conflicts in the practice of heritage conservation. Also, several particular articles show partially, narrow, and inappropriate in the term of academic view, which is quite disturbing that can lead to misunderstandings. In short, it can be highlighted that the current legislation and management of cultural heritage in Indonesia are still narrow, chaotic, and unparalleled to the global trend in heritage conservation. This situation becomes more complicated because of the government regulations as the implementation guide of the law has not been published yet. Meanwhile, the previous government regulations could no longer accommodate particularly to the newly concepts stated in the CB Law such as the category for conservation area/district and decentralization in the cultural heritage management and a multidisciplinary approach in the conservation work. Besides, despite over one 
hundred conventions, charters and international instruments on heritage conservation have been published until the present-day, but the only one that has been ratified by the Indonesian Government, namely Convention for the Safeguarding of the Intangible Cultural Heritage, 2003 into the Presidential Decree 78 of 2007. Meanwhile, many other Asian countries such as Japan, China, and Vietnam, as well as Malaysia, has repeatedly amended their heritage legislation, so that finally include protecting the intangible heritage.In addition, the CB Law No.11/2010 is still applying the old paradigm on cultural heritage conservation such as the heritage conservation still relies on the government, missing the concept of an active role in the community and integrated conservation which linked to the town planning. By looking the factual issues and the content of Law No.11/2010, the heritage legislation in Indonesia appears to be inadequate to ensure appropriate safeguarding the cultural heritage either tangible or intangible heritage. Therefore, it needs to be strengthened in certain regardsfor better protection and management in the future.

\section{REFERENCES}

Blake, J. (2000). On Defining the Cultural Heritage. The International and Comparative Law Quarterly, Vol. 49, No. 1, pp. 61-85.

Cheung, P. T. Y. (2011 ). Civic Engagement in the Policy Process inHongkong: Change and Continuity. Public Admin. Development, 31, 113-121. doi: 10.1002/pad.597.

Chirikure, S., \& Gilbert Pwiti. (2008). Community Involvement in Archaeology and Cultural Heritage Management: An Assessment from Case Studies in Southern Africa and Elsewhere. Current Anthropology, Vol. 49, No. 3, pp. 467-485.

Christina Aas, Ladkin, A., \& Fletcher, J. (2005). Stakeholder Collaboration And Heritage Management. Annals of Tourism Research, Vol. 32, No. 1, pp. 28-48.

Damais, S. (1978, September 26-28 1978). The Development of a Conservation Programme for Jakarta. Paper presented at the Conservation as cultural survival in the series Architectural.
Jokilehto, J. (1986). A History of Architectural Conservation. (PhD Thesis), University of York, York, pp.36-39.

Larkham, P., J. (1996). Conservation and the City. London: Routledge.

Macdonald, S. (2011). Leveraging Heritage: Public Private, and Third-Sector Partenerships for the Conservation of the Historic Urban Environment ICOMOS Open Access.

Meurs, P. (2007). A charter for each intervention: from generic to specific guidelines. City \& Time, 3 (3):4, p.53-60.

Prott, L. V., \& O'Keef, P. J. (1992). 'Cultural Heritage' or 'Cultural Property'? International Journal of Cultural Property, Vol.1 (No.02), pp 307-320.

Soebadio, H. (1985). Cultural policy in Indonesia. Paris: Unesco, pp.13.

Soekmono, R. (1992). Sedikit Riwayat 50 Tahun Lembaga Purbakala dan Peninggalan Nasional 1913-1963. Jakarta: Pusat Penelitian Arkeologi Nasional, pp.10-15.

Tanudirjo, D. A. (2007). Cultural Landscape Heritage Management in Indonesia An Archaeological Perspective. Paper presented at the The First International Symposium on Borobudur Cultural Landscape Heritage Yogyakarta.

Tanudirjo, D. A. (2010). Undang-undang Cagar Budaya 2010 dalam perspektif arkeologi Paper presented at the Diskusi Pembahasan UndangUndang tentang Cagar Budaya, Bogem, Kalasan, Sleman, DI Yogyakarta.

UNESCO. (1976). Nairobi Recommendation: International Recommendation concerning the Safeguarding and Contemporary Role of Historic Areas.

Yahaya, A. (2006). The Scope and Definitions of Heritage: From Tangible to Intangible International Journal of Heritage Studies, 12 (3), pp.292-300.

Zancheti, S. M., Hidaka, L. T. F., Ribeiro, C., \& Aguiar, B. (2009). Judgement And Validation In The Burra Charter Process: IntroducingFeedback In Assessing The Cultural Significance Of Heritage Sites. City \& Time 4(2): 5, 47-53. 